\title{
Designing Grazing Susceptibility to Land Degradation Index (GSLDI) in Hilly Areas
}

Gabriel MINEA ( $\square$ gabriel.minea@unibuc.ro)

University of Bucharest

Nicu CIOBOTARU

University of Bucharest

Gabriela IOANA-TOROIMAC

University of Bucharest

Oana MITITELU-IONUŞ

University of Craiova

Gianina NECULAU

University of Bucharest

Yeboah GYASI-AGYEI

Griffith University

Jesús RODRIGO COMINO

University of Granada

\section{Research Article}

Keywords: grazing, land degradation, regional approach, erosion, Curvature Subcarpathians

Posted Date: February 7th, 2022

DOI: https://doi.org/10.21203/rs.3.rs-1329577/v1

License: (c) (i) This work is licensed under a Creative Commons Attribution 4.0 International License.

Read Full License

Version of Record: A version of this preprint was published at Scientific Reports on June 21st, 2022. See the published version at https://doi.org/10.1038/s41598-022-13596-1. 
3

4

5 Gabriel Minea ${ }^{1,2 *}$,Nicu Ciobotaru ${ }^{1,2}$, Gabriela Ioana-Toroimac ${ }^{3}$, Oana Mititelu-Ionuș ${ }^{4}$, 6 Gianina Neculau $^{1,2}$, Yeboah Gyasi-Agyei ${ }^{5}$, Jesús Rodrigo-Comino ${ }^{6}$

7

8

9 10
7

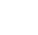

1 Research Institute of the University of Bucharest, 90 Sos. Panduri, 5th Sector, 050663 Bucharest, Romania

2 National Institute of Hydrology and Water Management, 97E București-Ploiești Road, 1st Sector, 013686 Bucharest, Romania

${ }^{3}$ Faculty of Geography, University of Bucharest, 1 Nicolae Bălcescu, 1st Sector, 010041, Bucharest, Romania

4 Department of Geography, Faculty of Sciences, University of Craiova, 13 A.I. Cuza Street, 200585 Craiova, Romania

${ }^{5}$ School of Engineering and Built Environment, Griffith University, Nathan QLD 4111, Australia

${ }^{6}$ Departamento de Análisis Geográfico Regional y Geografía Física, Facultad de Filosofía y

Letras, Campus Universitario de Cartuja, University of Granada, 18071 Granada, Spain

*Corresponding author: gabriel.minea@unibuc.ro

\section{Designing Grazing Susceptibility to Land Degradation Index (GSLDI) in Hilly Areas}


34 Abstract. Evaluation of grazing impact on land degradation processes is a difficult task due to heterogeneity and complex interacting factors involved. In this research, we designed a new methodology based on a predictive index of GSLDI (Grazing Susceptibility to Land Degradation Index) built on artificial intelligence to assess land degradation susceptibility in areas affected by small ruminants (SRs) of sheep and goats grazing impacts. The data for model training, validation, and testing consisted of sampling points (erosion and no-erosion) taken from aerial imagery. Seventeen environmental factors (e.g., DEM derivatives, small ruminants' stock), and 55 subsequent attributes (e.g., classes/features) were assigned to each sampling point. The impact of SRs stock density over the land degradation process has been evaluated and estimated with two extreme SRs' density scenarios: missing (0), and double density (overstocking). We applied the GSLDI methodology on the Curvature Subcarpathians, a region that experiences the highest erosion rates in Romania, and found that SRs grazing is not the major contributor to land degradation, accounting for only $4.6 \%$. This methodology could be replicated in other steep slopes grazing areas as a tool to assess and predict areas susceptible to land degradation, and to establish common strategies for good land-use practices.

Keywords: grazing; land degradation; regional approach; erosion; Curvature Subcarpathians 


\section{INTRODUCTION}

64

65

66

67

68

69

70

71

72

73

74

75

76

77

78

79

80

81

82

83

84

85

86

87

88

89

90

91

92

93

94

95

Unsustainable grazing is a millennial activity that can trigger land degradation processes if appropriate soil management practice is not put in place (Papanastasis and Peter, 1998; Oertel et al., 2016; Pulido et al., 2018). However, it is a vital activity that ensures food security (Staddon and Faghihinia, 2021) and ecosystems health (Gibbs and Salmon, 2015).

Pastoral land activities are some of the most common farming practices in many parts of the world such as central and southeastern Europe. Some representative areas are located in Poland and Romania (Morales et al., 2019; Wolański et al., 2021) and along the Pyrenees in Spain (Nadal-Romero et al., 2018). Livestock is in many countries the largest agricultural sector and occupies about $37 \%$ of the global ice-free land surface (130.4 $\mathrm{Mkm}^{2}$ ) (IPCC, 2019). Across the world, the domestic stock was estimated as 1,238 billion sheep and 1,094 billion goats in 2019 (FAOSTAT, 2021), which delivered 1/3 of all protein consumed by humanity (FAO, 2021). Small ruminants (SRs) stock (sheep and goats) can be considered as a major contributor to the global economy accounting for about 2\% (1995 to 2005) of the global gross domestic product (Steinfeld et al., 2006; Gomez-Zavaglia et al., 2020). In the context of increasing demand for food due to the growing human population, the environmental impact of various sectors of agriculture will also increase (Ritchie and Roser, 2017). The increasing combined pressure of agricultural and livestock productions (e.g., unsustainable grazing) are assumed as one of the main factors expected to accelerate land degradation in the $20^{\text {th }}$ and $21^{\text {st }}$ centuries $(\mathrm{WHO}$, 2020). Soil erosion in agricultural areas (Borrelli et al., 2017; Rodrigo-Comino, 2018; Niu et al., 2021; Zamfir and Crişu, 2021) and intensive grazing are recognized as global environmental issues (Turnbull et al., 2010; Goodarzi et al., 2021).

Grazing, as a component of land use, is associated with certain patterns in hydrosedimentary conditions from event-scale to the catchment scale (e.g., Bartley et al., 2007; RodriguezLloveras et al., 2015) and several studies have analyzed the relationship between unsustainable grazing, grassland status, and animal types (e.g., Warren et al., 1986; Heathwaite et al., 1989; Mwendera and Saleem, 1997; Meyles et al., 2003; Pande and Yamamoto, 2006; Kidron, 2016; Pulley and Collins, 2019; Lai and Kumar, 2020). Unsustainable and prolonged grazing may trigger hydrological changes such as soil water content, but also the activation of runoff with an impact on the streamflow regime (e.g., maximum and minimum flow) affecting runoff coefficients (Gifford and Hawkins, 1978; Gifford et al., 1983; Markart et al., 2006; Sadeghi et al., 2007; Ruggenthaler et al., 2015), even with modifications of the terrestrial water (Vörösmarty and Sahagian, 2000). For example, Meyles et al. (2006) assessed flood frequency 
with a higher occurrence of erosion on large areas under intensive grazing process in a small Dartmoor catchment, southwest England. Poesen (2018) stressed the need for more research attention on the hydrological and erosional response of rangelands. Hancock et al. (2020) quantified erosion in a grazing environment typical of the east coast of Australia and discovery that under current management practices soil loss is relatively low ( $<5$ tonnes/ha/yr).

Most hydrological studies have underlined the role that vegetation plays in grazing lands in controlling erosion (Blanco-Canqui and Lal, 2008) and the biocrust (Kidron et al., 2021; Lázaro et al., 2021). Some authors pointed out that about $20 \%$ of the world's pasture areas are considered degraded as a consequence of overgrazing and associated erosion and compaction among other main factors (Steinfeld et al., 2006). Nowadays, scholars have highlighted that this relation is complicated and not well understood. One of the most complex mechanisms is related to the SRs where they can influence organic matter and facilitate the adherence of aggregated clay and the formed colluvial layer that serves as a substrate to the expanded vegetation growth (Kulik et al., 2013; Mor-Mussery et al., 2021). Moreover, satellite-derived data as Normalized Difference Vegetation Index (NDVI) can be used in land degradation assessments, but without distinguishing specific signs of degradation/conservation from impacts of adverse/beneficial natural processes (Gibbs and Salmon, 2015; Riva et al., 2017). In the last few years, and the temperate climate of Europe, the analysis of SRs grazing influence on soil and runoff processes has received minimal interest. A few field works have been carried out at the hillslope scales under grazing (e.g., Heathwaite et al., 1990; Cerdà et al., 1998; Meyles et al., 2003; Ries et al., 2014; Bond et al., 2020).

Some previous methods and tools used for the quantification of grazing as part of land degradation and erosion have shown several drawbacks. For example, field-based monitoring has to be planned for very long-term periods to foresee future changes, which may become expensive and time-consuming (Peppler and Fitzpatrick, 2004). Therefore, the lack of monitoring and observational data is hampering the assessment of land degradations by grazing. Nowadays, remote sensing techniques and modeling approaches based on landscape unit and vegetation indexes are becoming useful tools. Riva et al. (2017) showed that grazing is a significant cause of land degradation even in partially abandoned areas, and the effectiveness of responses to land degradation is substantially affected by land cover and topography.

Given the spatial and temporal variability of various grazing practices that complicates the interpretation within mechanistic models, Ma et al. (2019) highlighted that efforts are needed to reduce inconsistencies among grazing land models in simulated grazing management effects 
by carefully examining the underlying processes interacting in each model. Also, interesting results were obtained by Kosmas et al. (2015) using Geographical Information Systems (GIS) at the local scale, concluding that rapid growth in the livestock density increased soil erosion rates. Thus, the relationship between land degradation, erosion, and unsustainable grazing is poorly understood and should be further assessed.

Degraded land occupies over $2 \%$ of the land in Romania due to corroboration of natural and anthropogenic causes (Costea, 2013). Recent studies confirmed land degradation by soil erosion (Prăvălie et al., 2017), gullying and landslides (Bălteanu et al., 2010), and reservoir sedimentation (Niacsu et al., 2021), and that statistics of stocking rate and grazing deviate from the optimum (Roman et al., 2019). For the Southern Carpathian Mts., the Romanian, transhumance of sheep prevents the development of serious erosion in otherwise erosion-prone areas that can support little beyond livestock raising (Shirasaka, 2007). Surprisingly, Nicu (2018) found that overgrazing is not influencing or accelerating soil erosion on gullies in the Bahluiet River catchment in the northeastern part of Romania. In this context, land degradation under grazing activities is a serious problem in hilly areas of Romania and effective soil conservation is urgently needed. Yet, it remains a knowledge gap in the quantification of the role of grazing among numerous factors on erosion and land degradation in past interdisciplinary investigations at the regional scale. Filling the gap of quantifying the complexity of land degradation drivers could help decision-makers in spatial planning and agriculture to set guidelines for land-use policy.

Therefore, this paper starts from the hypothesis that land degradation and grazing can be assessed using multiple environmental factors and even at larger scales.

The main aim of this research is to quantify the relation between grazing impacts of SRs on land degradation processes using the Grazing Susceptibility to Land Degradation Index (GSLDI). The specific objectives are:

(1) to develop a novel model using a qualitative assessment of the evidence-support of a hypothesis that integrates weight/partitive factors of land degradation at a regional scale; and (2) to investigate a hilly region in Romania (the Curvature Subcarpathians) that is characterized by the highest rates of erosion and SRs density with GSLDI. 


\section{METHODS AND DATA}

163

164

165

166

167

168

169

170

171

172

173

174

175

176

177

178

179

180

181

182

183

184

185

186

187

188

189

190

191

192

\subsection{Models description}

Based on the recent approach by Costache et al. (2021a, 2021b) and Vojtek et al. (2021), we developed new advancing land degradation knowledge and the SRs grazing pressure using machine learning (ML) algorithms.

The proposed modeling framework consists of: i) land erosion inventory (manually identifying erosion and no-erosion sampling points based on aerial imagery); ii) assigning the geographical characteristics (17 parameters, e.g., lithological structure, altitude), iii) standardizing the dataset (55 subsequent attributes e.g., classes/features), and iv) model training (ML process).

\subsection{Data processing}

The database for land erosion inventory requires compulsory sampling points (vector data) exhibiting erosion or no-erosion processes detected using open sources imagery (e.g., Google Earth, Bing) for the study area. Manual collecting sampling points procedure necessities available more time work and should be harmonized (checks, validation) with the laboratory staff. Moreover, the point's survey density can be varied between low (e.g., forest sites) and high (land-use fragmentation) and should be agreed upon according to the land-use characteristics.

A database with 17 geographical parameters (Figure 1) converted in thematic layers were extracted from the Digital Elevation Model (e.g., curvature, slope terrain); lithology and soil maps; vegetation features (e.g., Corine Land Cover); rainfall erosivity (Panagos et al, 2015), and SRs parameters (stock and densities) was established to train and validate the proposed model. Available vector (e.g., boundary shapefile for the geomorphologic region and the Local Administrative Units - LAU) and raster format data (e.g., at medium-precision, the scale of 1:25,000) and large maps (e.g., lithological and pedological maps 1:200,000) are required in the database. We chose a regional geographical approach combined with the stock density data of small ruminants mainly because SRs rank as land degradation significant variables.

To implement this analysis, several spreadsheet calculations were required, followed by geospatial processing (e.g., vector to raster format; union/merge, reclassify). Here, we work with a grid at 30 meters horizontal spatial resolution, also resamples are necessary (Figure 1). 
Figure 1. The proposed hierarchy predictors and their geographical use to develop the Grazing Susceptibility to Land Degradation Index. (GRAVIPA = Grassland Vegetation Probability Index; LULC = Land Use Land Cover)

Model training procedure consisted in selecting the two models for classification Random Forest (RF), and Gradient Boosted Machine (GBM), which were evaluated with a confusion matrix and by accuracy, specificity, sensitivity, ROC (Receiver Operator Characteristic) curve, and Area Under the Curve (AUC) curve efficiency metrics. RF and GBM models performed very well in the training, validation, and testing sessions (accuracy estimated over 90\%). In the GIS environment of the model requires an association of 17 geographical features (e.g., lithological structure, altitude) with subsequent attributes (e.g., classes/features) for each sampling point (Figure 1 and Figure 2). Classes of geographical features (e.g., elevation range) have been determinated based on a statistical approach (e.g., Natural breaks classification.

In order to calculate the GSLDI, the models were trained to predict the erosion exposure by using the 17 attributes and their classes as predictors, resulting in the probability to have erosion processes on each pixel of the study area. The model set-up consists of randomly splitting the data (erosion and no-erosion points) into three categories: training set (80\%), spllitted again in training, and validation sets ( $10 \%$ of the training set, spllitted other 10 folds) during the crossvalidation procedure, and the final test set, which included $20 \%$ of the data, used to evaluate the model performance on an independent data set, which was not used in the training phase (Figure 2).

To evaluate and estimate the impact of SRs stock density over the land degradation process, we propose two SR's density scenarios: one considered 0 (missing), and another one with double density (overstocking).

The outcomes are planned to be presented as a probabilistic map of a chance between 0-100 percent to have exposure to the land degradation process concerning SRs, resulting in a map of land degradation (Figure 2).

The results of the analysis were plotted in a GIS environment, using the QGIS version 3.20 software, and R programming language with RF, caret, GBM, and other packages.

\section{Figure 2. Workflow for designing Grazing Susceptibility to Land Degradation Index}




\subsection{Classification algorithms}

Numerous studies have used Random Forest (RF) models to evaluate the erosion process, including Gayen et al. (2020), Mosavi et al. (2020), Amare et al. (2021). Random decision forests were first introduced by Ho (1995) who added randomness in the decision trees with increased accuracy for both training and unseen data. This method builds multiple trees in randomly selected subspaces of the feature space" and generates the final output by averaging results from all created decision trees. By this way, the bias is reduced and the accuracy improves. RF is a method of ensemble learning by combining multiple decision trees over the same classification task. The output of the RF algorithm is the class that is selected by most trees in the forest.

Given $t$ trees created in random subspaces, a discriminant function is used to combine the classification result by assigning $x$ to class $c$ and optimize the function $g_{c}(x)$ defined as (Ho, 1995):

$g_{c}(x)=\frac{1}{t} \sum_{j=1}^{t} \hat{P}\left(c \mid v_{j}(x)\right)$

In eqn (1) $\hat{P}$ is the optimum posterior probability that a point $x$ belongs to class $c(c=1,2 \ldots \mathrm{n})$ and is computed as the fraction of class $c$ points to the overall number of points that are assigned to $v_{j}(x)$ given as:

$$
P\left(c \mid v_{j}(x)\right)=\frac{P\left(c, v_{j}(x)\right),}{\left.\sum_{i=1}^{n} p\left(c_{l}, v_{j}(x)\right)\right)}
$$

where $v_{j}(x)$ is the terminal node of point $x$ when it descends down tree $T_{j}(\mathrm{j}=1,2, \ldots \mathrm{t})$.

Gradient Boosted Machine (GBM) has also been used in soil degradation/erosion susceptibility studies in different forms (Arabameri et al, 2020, 2021; Sahin 2020) and was first introduced by Friedman et al. (2000). Gradient boosting is also an ensemble model, comprising of decision trees. The difference between RF algorithms and GBM is that the combining process is done at the beginning of the tree in the case of GBM while for RF it is done at the end. Also, while RF builds each tree independently, GBM works by building one tree at a time, introducing a weak learner to improve the shortcomings of existing weak learners.

Let $\left\{\left(x_{i}, y_{i}\right)\right\}_{i=1}^{n}$ be the training dataset and $L(y, F(x))$ the loss function, $F$ being the model predicted values $\hat{y}=F(x)$ where $y$ represents the predicted value, and $\hat{y}$ is the optimum predicted value. First, the algorithm initializes with a constant value as: 


$$
F_{0}(x)=\arg \min _{\rho} \sum_{i=1}^{N} L\left(y_{i}, \rho\right) .
$$

259

260

261

262

263

264

265

266

267

268

269

270

271

272

273

274

275

276

277

278

279

280

281

282

283

284

285

286

287

288

289

Next, for $m=1$ to $M$ :

1. Compute the pseudo-residuals as:

$$
y_{i}=-\left[\frac{\partial L\left(y_{i}, F\left(x_{i}\right)\right)}{\partial F\left(x_{i}\right)}\right]_{F(x)=F_{m-1}(x)}, i=1, N
$$

2. Fit a weak learner by training it on the training set as:

$$
a_{m}=\arg \min _{a, \beta} \sum_{i=1}^{N}\left[\widetilde{y}_{l}-\beta h\left(x_{i} ; a\right)\right]^{2}
$$

3. Solve optimization problem as:

$$
p_{m}=\arg \min _{p} \sum_{i=1}^{N} L\left(y_{i}, F_{m-1}\left(x_{i}\right)+p h\left(x_{i} ; a_{m}\right)\right)
$$

4. Update the model as:

$$
F_{m}(x)=F_{m-1}(x)+p_{m} h\left(x ; a_{m}\right)
$$

Thus, a gradient boosting machine involves combining multiple weak classifiers in order to obtain a stronger one of the ensemble model.

\subsection{Model efficiency and accuracy evaluation}

In order to train the ML models, it was necessary to standardize the different measurements and the qualitative attributes of points (e.g., soil texture) to the same scale with the help of the "scale" function of the "dummies package" (Brown, 2021) of the R programming language. The cross-validation technique was used in the caret package in R (Kuhn, 2008) to randomly select the training and validation datasets in 10 folds for both models.

The training was conducted using cross-validation, which randomly partitions the dataset into complementary subsets of training and testing in order to test the model's ability to predict new data that was not used for training. Evaluation of model performance is a critical step towards the classification model selection criteria. The model results were evaluated using a confusion matrix and testing the accuracy, specificity, sensitivity, ROC curve, and AUC curve efficiency metrics (Kuhn, 2008).

The criteria used to evaluate the models are presented below:

Sensitivity $=\frac{T P}{T P+F N}$

Specificity $=\frac{T N}{T N+F P}$

$A U C=\frac{\sum_{n}^{i} T P+\sum_{n}^{i} T N}{(P+N)}$

where $T P=$ true positive, $T N=$ true negative, $F P=$ false positive, $F N=$ false negative, $P=$ all positives, and $N=$ all negatives. 


\subsection{Geographic Background of Survey Area}

291 We adopted for the survey of GSLDI a geomorphological unit for 3 reasons; relative geomorphological homogeneity (Posea and Badea, 1984), being one of the largest areas with historical land degradation (badlands) in Romania (Ielenicz, 1984; Jurchescu et al., 2020), and having the highest value of sediment yield (Diaconu, 1971; Ionita et al., 2006). However, this research starts from the premise that land degradation processes are also due to other local and regional factors (e.g., lithology, morphology, land use). The land-use changes should be considered, as well as agricultural practices such as grazing. Therefore, it was necessary to apply an integrated analysis of the possible determinant factors' assembly to understand and manage the land degradation in the Curvature Subcarpathians.

300 The Curvature Subcarpathians $\left(6,792 \mathrm{~km}^{2}\right)$ is a geomorphologic region in the central part of

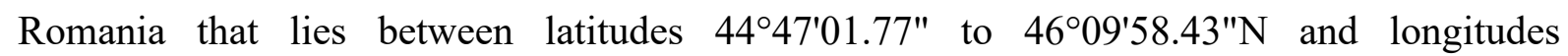
$24^{\circ} 11^{\prime} 13.00^{\prime \prime}$ to $27^{\circ} 59^{\prime} 34.82^{\prime \prime} \mathrm{E}$ (Stereographic 1970 projection), having a southern border with the Curvature Carpathians Mts (Figure 3). The study area is prone to land degradation, mainly erosion, due to both natural and socio-economic drivers (e.g., historical deforestation). The estimated peak erosion in Romania occurs in the Curvature Subcarpathians with rates between 30 and $45 \mathrm{t} \mathrm{ha}^{-1} \mathrm{y}^{-1}$ (Ionita et al., 2006). Besides denudation, the Curvature Subcarpathians are characterized by various types of slope processes such as landslides, earth flows, and falls (Micu, 2017), and also by an intense vertical erosion mirrored by incised river valleys (Buzău, Ialomiţa and Teleajen Rivers) (Chendeș, 2011). The lithology and seismicity explain the susceptibility to landslides (Broeckx et al., 2016), the predominance of low cohesive rocks, sandy clay loam and clay soils, and active neotectonic movements (Armaș, 2012; Micu, 2017; Jurchescu et al., 2020). Deforestations, which is still continuing, may also trigger gravitational processes. The natural vegetation (e.g., broad-leaved forests) has been replaced by human activities into secondary grasses, orchards, vineyards, and croplands. The road network has amplified the disequilibrium of slopes.

316 The Curvature Subcarpathians receive approximately $600-700 \mathrm{~mm}$ of precipitation per year, 317 the maximum occurring in summer (up to $100 \mathrm{~mm} / \mathrm{month}$ ), and the lowest in autumn and winter 318 (Zaharia et al., 2011). Summer months are characterized by heavy rains that transform into overland flow causing aggressive erosion, especially on the bare soil (Chendeș, 2011). The study area appears to be among the regions with the national highest maximum rainfall intensity of for $5 \mathrm{~min}$ duration and 1:10 years return period (e.g., 1.48-1.86 mm/min reported by Cheval et al. (2012). 
323 Rivers draining the Curvature Subcarpathians transport large amounts of suspended sediment

324

325

326

327

328

329

330

331

332

333

334

335

336

337

338

339

340

341

342

343

344

345

346

347

348

349

350

351

352

353

354

355

356

load (Olariu et al., 2014). As a consequence, the largest rivers form a sandy braided pattern, laterally unstable (Ioana-Toroimac, 2016). Also, the study area is characterized by the highest suspended sediment yield in Romania (Diaconu, 1971; Zaharia et al., 2011). The mean specific suspended sediment yield is about 20-25 $\mathrm{tha}^{-1} \mathrm{yr}^{-1}$, while the sediment concentration exceeds $25,000 \mathrm{~g} \mathrm{~m}^{-3}$ (Zavoianu et al., 1996). The highest suspended sediment load occurs in spring and summer during the high-water phase of the hydrological regime or during floods when the fluvial erosion or erosion processes on slopes are more intense. It is observed that the variability of the suspended sediment load is higher than the variability of the mean annual water discharge (Zaharia and Ioana-Toroimac, 2009).

Figure 3. The location of Curvature Subcarpathians and the border of Local Administrative Units level 2

\section{RESULTS AND DISCUSSIONS}

\subsection{Assessment of parameters}

Firstly, we mapped 4187 sampling points for Curvature Subcarpathians with erosion or noerosion processes from Google, Esri, and Bing imagery, available for August 2021, using the HCMGIS plugin from QGIS 3.20. Even though imagery has been taken at different periods, using three sources allowed the observers to check if the zone is not erroneously classified as erosion or no-erosion point. It resulted in a database with $61 \%$ of the points classified as erosion and the rest of them as no-erosion points.

From geo-spatial.org, we extracted these datasets containing vector geospatial information such as LAUs Boundary dataset; localities dataset, hydrography features dataset and DEM at 30 meters spatial resolution as raster format. Some datasets have been resampled to $30 \mathrm{~m}$ (e.g., Tree Cover Density). More relevant morphometric parameters/factors (e.g., slope; profile curvature) was derived from DEM. Lithological and soil features were extracted from the Geological Map of Romania (1:200,000), and the Soil Map of Romania $(1: 200,000)$ respectively. LAUs (formerly NUTS level 5) were used as the smallest territorial subdivision by the Nomenclature of Territorial Units for Statistics (NUTS) for statistical purposes (see Supplementary 1$)$. 
Therefore, each sampling point has 17 geographical attributes as presented in Table 1. In Figure 4, some predictors (such as lithology, soil properties, and land use land cover) are mapped.

Table 1. Parameters used for training the sampling points

GRAVPI $=$ Grassland Vegetation Probability Index; LULC $=$ Land Use Land Cover.

Some particularities of geographical attributes associated with erosion and no-erosion sampling points in the Curvature Subcarpathians are briefly debated.

The lithological structure (IGR, 1968) of the study region is dominated by Clays, Sands, and Conglomerates, indicating that the under-soil layer is unstable.

Altitude, Slope, and Aspect were extracted from the Digital Elevation Model with the resolution of $30 \mathrm{~m}$, created from topographical maps of scale 1:25,000 (ANCPI, 2021). The classes and percentage shares of the total area are presented in Table 1. The altitudes are generally moderate $300-500 \mathrm{~m}$, slopes are moderate (10-15\%) to steep (15-25\%) in $45 \%$ of the total area, while mild slopes (5-10\%) dominate the landscape of the region, especially in the Plains and at the foothills. Aspect favors the exposure to the sun in general, the slopes being east, south-east, south, and southwest facing in over $57 \%$ of the area. Thus, the Curvature Subcarpathians region has a high isolation value which favors evapotranspiration, which in turn reduces the water availability, favoring the presence of thermophile vegetation such as vineyards, oak, tilia forest, or common lilac.

Curvature is the second derivative of the land surface, indicating the exposure to erosion of the landform area (Dehn, 2001). Profile curvature influences the acceleration/deceleration of flow while plan curvature indicates the concentration of flow on the land surface. Both profile and plan curvatures are indicators of the rate at which erosion and accumulation take place. These two characteristics values ranging between -0.5 and 0.5 are not considered very active regarding the erosion process, while the values above or below these thresholds represent areas most exposed to the erosion process. The total curvature combines these two indicators, and more than $8 \%$ of the territory is very exposed to the erosion process, compared with less than $3 \%$ when using profile and plan curvature.

Topographical Positioning Index (TPI) classifies the relief in different topographical units based on a change in altitude compared with the mean altitude of transect with a radius of 1 $\mathrm{km}$ (Weiss, 2001). TPI describe the main landforms of the Subcarpathians region, resulting in over $52 \%$ of the relief occupied by flood plains combined with the base of the hills (basin) 
390

391

392

393

394

395

396

397

398

399

400

401

402

403

404

405

406

407

408

409

410

411

412

413

414

415

416

417

418

419

420

421

422

423

landforms, while the torrential valleys, most exposed to the erosion process, have a share of $13 \%$ of the total area.

Distance to Streams can be related to the erosive action of the river channels as the closer to the river channel the greater the chance to encounter land degradation processes. Therefore, this indicator allows us to create a relation between the observed soil degradation places and the distance to the stream channel. This indicator has been extracted from a drainage network of support threshold of $1 \mathrm{~km}^{2}$ catchment area.

Corine LULC layer has been used in the study area as the main nomenclature for land use with a spatial resolution of 1 ha also, has been resampled to $30 \mathrm{~m}$. It has been divided into 9 classes (label 3), of which 18\% are covered by agricultural land, 7\% are built areas and almost $6 \%$ are represented by vineyards and trees. The most important two classes are forests $(47 \%)$ and pastures and grasslands (20\%).

Grassland Vegetation Probability Index (GRAVPI) constitutes an expert product estimation from the Copernicus Land Monitoring service (Langanke, 2018; Zeug et al., 2020) and is used to represent the spatial distribution of grassland areas within the study zone in a raster with the resolution of $30 \mathrm{~m}$. From this layer, we can observe that almost $87 \%$ of the area is covered with LULC types other than grassland areas. This is caused by the fact that the herbaceous zones are mixed with trees or bare land and agricultural land, making it difficult to identify this type of LULC, and in general, is underestimated compared with Corine Land Cover (CLC) 2018.

Tree Cover Density from Copernicus Land Monitoring service (EEA, 2018) represents the density of trees (between 0 to 100\%) in forested and non-forested areas in 2018, pixels having a resolution of $20 \mathrm{~m}$. The dataset has been resampled to $30 \mathrm{~m}$ to conform to the same resolution of the other layers used in the analysis.

The survey area has a forest cover of over $63 \%$, of which $47 \%$ is in patches with densities above $80 \%$, thus considered as a compact forest. The overall cover of $63 \%$ is an overestimation of the forest cover, compared with the CLC layer, were only $47 \%$ of the study zone is represented by forested areas. This difference is explained by the fact that tree cover density is evaluated in all patches of trees, without considering the mixture of pastures or agricultural areas with the trees.

Hydrologic Soil Groups represent the rate at which water infiltrates into the soil, Soil group A is the most porous (with over $7.6 \mathrm{~mm} / \mathrm{hr}$ infiltration rate) while the Group D corresponds to soils with lower permeability (0 $-1.3 \mathrm{~mm} / \mathrm{hr}$ ) (Mockus, 2012). This dataset has been derived from soil texture classes of Romanian Soil dataset 1:200,000 (Vintilă et al., 2004), using that the method developed by Drobot (2007). The areas with low permeability (Group D) are the 
most exposed to soil erosion, favoring surface and rill erosion in the Curvature Subcarpatians. These soils cover almost $30 \%$ of the study area while Group B soil has a similar share with almost $32 \%$ of the study area.

Curve Number (CN) (Mishra and Singh, 2003) is an indicator of the land capacity to absorb the water into the soil, and the higher its value the lower the infiltration. For the Curvature Subcarpathian region, the soils having low infiltration rates $(\mathrm{CN}>70)$ covers almost $60 \%$ of the area, a situation that favors runoff and surface erosion.

Rainfall Erosivity, known as R-factor (Panagos et al, 2015), is another indicator of soil exposure to erosion caused by rainfall drops. This indicator was taken from the "European Soil Data Center - ESDAC", and represents the multi-annual erosion capacity of rain. For the study region, over $70 \%$ of the land has an average rainfall erosivity of over $800(\mathrm{Mj} \mathrm{mm} / \mathrm{ha} \mathrm{h} \mathrm{yr})$, which can be considered as a medium-high value compared with values across the country. Soil Texture (Vintilă et al., 2004), in the study region, is dominated by the Clay Loam class (> $81 \%$ ), which corresponds to soils with low permeability, favoring runoff and erosion.

The SRs density data were derived by considering the number of goats and sheep, in each LAU (GAC 2010,2011) to the official area of land used as pastures in the cadastral evidence (AGR 101B, 2021). The 2010 share of SRs has been transferred to the 2019 counts at the county level per each LAU, thus, a more recent and accurate density is acquired (Neculau et al., 2021). This data has been prepared into a raster of the densities per each LAU, and it shows high variability in space making is a good explanatory variable, as long as it is spatially non-homogeneous and exhibits a bell curve distribution.

Pasture surfaces data were obtained from the National Institute of Statistics of Romania by considering the land fund corresponding to "pastures' of each Local Administrative Units at level 2 (LAUs) within the Subcarpathians region (INSSE, 2021b). Curvature Subcarpathians region shows a high national average stocking density of SRs (sheep and goats) of about 4.7 units per ha, with uneven territorial distribution $(\mathrm{SD}=9.26)$ (see Supplementary 1).

Figure 4. Curvature Subcarpathians geographic factors: a. Lithology; b. Slope angle; c. Aspect; d. Profile Curvature; e. Forest and Trees Patches Cover Density; f. GRAVPI; g. Hydrologic Soil Groups; h. Curve number; i. SRs Density. 


\subsection{GSLDI application}

Model configuration indicates that grazing of SRs plays a low role in the exposure to land degradation process, being the sixth important parameter among the 17 geographical variables, and contributing to $4.55 \%$ of the whole exposure in the Curvature Subcarpathians region.

The ranking of the relative influence shows the highest values for forest (43.7\%) and terrain variables (e.g., slope 18.7\%; profile curvature 7.19\%) in the Curvature Subcarpathians region (Figure 5).

Figure 5. Conditional factors and their relative influence (\%) / share/rank (\%) to land degradation in the Curvature Subcarpathians region under GBM

In order to assess the grazing impact of SRs and build the GSLDI over the study region, we work with two major scenarios: the absence (0\%) and overstocking of $100 \%$ (Figure 6).

The absence of grazing pressure signals a decrease of erosion likelihood exposure in the GBM model, while for RF model signals and increase in exposure. An increase of $100 \%$ of the grazing pressure indicates an increase in erosion likelihood exposure in both models, suggesting that grazing activity is one of the factors that control erosion exposure in the Curvature Subcarpathians region (Figure 6).

Figure 6. GSLDI probabilistic maps (0 -100\%) in CS region with Random Forest (top 3 images) and Gradient Boosted Machine (bottom 3 images) under initial (a), zero (b), and $100 \%$ overstocking (c) scenarios

Model training with RF and GBM algorithms performed very well, having the same accuracy, over $90 \%$, and were selected for the mapping of land degradation in the Curvature Subcarpathian's region (Table 2; Figure 7).

Table 2. Model efficiency (\%) according to multiple efficiency criteria $\mathrm{RF}=$ Random Forest GBM $=$ Gradient Boosted Machine; AUC $=$ Area Under the Curve; ROC $=$ Receiver Operator Characteristic.

Figure 7. ROC curves with associated AUC values computed from Gradient Boosted Machine and Random Forest 


\section{CONCLUSIONS: REFLECTIONS AND FINAL REMARKS}

495 We proposed a new methodology based on specific parameters chosen to evaluate small ruminants' (SRs) grazing contribution to land degradation. A novel model has been developed using a qualitative assessment of the evidence-support of a hypothesis that integrates weight/partitive factors of land degradation at the regional scale.

499 The new tool shows land degradation susceptibility under SRs grazing impact which allows us to present a basic knowledge of the impressive factors for land degradation occurrence under

501 SRs grazing pressure.

502 In our study case, the modeling framework has been consisted of sampling erosion and noerosion points (4187 sampling points), assigning the physical and geographical characteristics

504 (17 attributes), standardizing the dataset (55 final attributes), and using them in the training ML models of RF and GBM. The GSLDI indicates that SRs grazing plays an important role, but is not the major factor in the exposure to erosion process, contributing to only $4.6 \%$ of the whole exposure to land degradation, according to GMB model rank classification. However, this low percent agrees with the findings of Nicu (2018) who reported for a gully assessment in the northeastern part of Romania that overgrazing does not considerably change the erosion rates. Another explication to land degradation and the high value of erosion rates could be the lithology and neo-tectonic movements (uplift rates of 3-4 m/year) (Micu and Balteanu, 2009).

512 Although, the results have some uncertain stemming from (i) the low-quality resolution of the 513 biophysical predictors; (ii) the required supplementation with field monitoring for evidence in 514 agricultural catchments for quantitative evidence of erosion rates.

515 Now a critical question here is why the results are different and which one is telling the truth?

516 We found for the areas covered by pastures, natural grasslands, or other grasslands

517 (Sclerophyllous vegetation, sparsely vegetated areas), the scenario with the absence of grazing 518 pressure signals a small decrease of erosion likelihood exposure with the GBM model, while 519 for RF model signals an increase in exposure (Table 3). This may indicate that the model sensitivity to this factor is low and not enough to observe the impact of the grazing pressure for RF model. An overstocking of $100 \%$ of the grazing pressure indicates a small increase in erosion likelihood exposure for the GBM model, which may indicate again the not major role of the grazing activity in the control to erosion exposure in the Curvature Subcarpathians area (Table 3). 
The presence of forests plays a crucial role in land degradation through erosion. More precisely, the forest vegetation density has a relative influence share of approximately $33 \%$ in explaining the susceptibility to land degradation. Approximately $11 \%$ of results are explained by the simple presence of forest, without regard to any other particular features. This is a very important result confirming that not necessarily the presence of the forest is important, but more important is the presence of tall vegetation with high density that could be named or classified otherwise. This might explain why authors such as Broeckx et al. (2016) show a very weak correlation with sediment yield in the agricultural catchment with strongly contrasting land uses in their work about sheet and rill erosion rates in Romania. Therefore, for future studies on erosion susceptibility or land degradation, we also recommend the use of forest vegetation density instead of simply forest. In the long term, a more adapted classification of grazing range/scale would be necessary to avoid the risk of overestimating the availability potential of land degradation areas.

We did not exclude or minimize the role of grazing impact of SRs, especially at the local scale (Figure 8), but over time will result in complex interactions depending on environmental factors. However, a quantitative known grazing impact of SRs, as pointed out by Evans (1997), Poesen (2018), Boardman et al. (2019), needs observation and empirical survey (e.g., sediment traps and chemical fingerprinting) to understand the hillslope process and the extent of rates of erosion.

Figure 8. Sheet and linear grazing impact of SRs photos - near paddock (left) and trails (right) in the Curvature Subcarpathians (Romania); photograph taken by Gabriel MINEA on August $18^{\text {th }}, 2021$

We conclude that a better knowledge of the relationship between SRs and land use can be beneficial to society and the environment (e.g., soil conservation, hazard management, subsidy, mitigation measures). Overall, we consider that the proposed GSLDI can be used efficiently to assess land degradation concerning small ruminant grazing in other land degraded regions. Finally, we argue that land degradation induced by SRs can be assessed with success using the GSLDI approach. Also, the GSLDI is helpful as basic support to promote agricultural sustainable policies at the regional-level decisions regarding grazing farming practices.

\section{Supplementary Material S1}


563

564

565

566

567

568

569

570

571

572

573

574

575

576

577

578

579

580

581

582

583

584

585

586

587

588

589

590

591

592

593

594

595

596

597

598

599

600

601

602

603

604

605

606

607

608

609

610

ANCPI. (2021). National Agency for Cadastre and Land Registration. Digital Elevation Model of Romania (Geoportal ANCPI).

AGR101B. (2012). Land fund area by usage, counties and localities] National Institute of Statistics of Romania. https://insse.ro/cms/en.

Arabameri, Alireza, Wei Chen, Marco Loche, Xia Zhao, Yang Li, Luigi Lombardo, Artemi Cerda, Biswajeet Pradhan, and Dieu Tien Bui. (2020). Comparison of machine learning models for gully erosion susceptibility mapping. Geoscience Frontiers 11, no. 5 16091620.

Arabameri, A., Chandra Pal, S., Costache, R., Saha, A., Rezaie, F., Seyed Danesh, A., Pradhan, B., Lee, S. and Hoang, N.D. (2021). Prediction of gully erosion susceptibility mapping using novel ensemble machine learning algorithms. Geomatics, Natural Hazards and Risk, 12(1), pp.469-498.

Amare, S., Langendoen, E., Keesstra, S., Ploeg, M. V. D., Gelagay, H., Lemma, H., \& van der Zee, S. E. (2021). Susceptibility to Gully Erosion: Applying Random Forest (RF) and Frequency Ratio (FR) Approaches to a Small Catchment in Ethiopia. Water, 13(2), 216. https://doi.org/10.3390/w13020216

Armaş, I., (2012). Weights of evidence method for landslide susceptibility mapping. Prahova Subcarpathians, $\quad$ Romania. Nat. Hazards 60(3), 937-950. https://doi.org/10.1007/s11069-011-9879-4

Bartley, R., Hawdon, A., Post, D. A., \& Roth, C. H. (2007). A sediment budget for a grazed semi-arid catchment in the Burdekin basin, Australia. Geomorphology, 87(4), 302-321. https://doi.org/10.1016/j.geomorph.2006.10.001

Bălteanu, D., Chendeş, V., Sima, M., \& Enciu, P. (2010). A country-wide spatial assessment of landslide susceptibility in Romania. Geomorphology, 124(3-4), 102-112. https://doi.org/10.1016/j.geomorph.2010.03.005

Blanco-Canqui, H., Lal, R. (2008). Erosion and Grazing Lands. In: Blanco-Canqui, H., Lal, R. (eds.) Principles of Soil Conservation and Management. Springer, Dordrecht, 345-398. https://doi.org/10.1007/978-1-4020-8709-7

Bond, S., Kirkby, M.J., Johnston, J., Crowle, A., Holden, J. (2020). Seasonal vegetation and management influence overland flow velocity and roughness in upland grasslands. Hydrol. Process. 34(18), 3777-3791. https://doi.org/10.1002/hyp.13842

Borrelli, P., Robinson, D.A., Fleischer, L.R., Lugato, E., Ballabio, C., Alewell, C., Meusburger, K., Modugno, S., Schütt, B., Ferro, V., Bagarello, V., Oost, K.V., Montanarella, L., Panagos, P. (2017). An assessment of the global impact of 21st century land use change on soil erosion. Nature Communications 8. https://doi.org/10.1038/s41467-017-02142-7

Boardman, J., Vandaele, K., Evans, R., \& Foster, I. D. (2019). Off-site impacts of soil erosion and runoff: Why connectivity is more important than erosion rates. Soil Use and Management, 35(2), 245-256, http://dx.doi.org/10.1111/sum.12496.

Broeckx, J., Vanmaercke, M., Bălteanu, D., Chendeş, V., Sima, M., Enciu, P., \& Poesen, J. (2016). Linking landslide susceptibility to sediment yield at regional scale: application to Romania. Geomorphology, 268, 222-232. https://doi.org/10.1016/j.geomorph.2016.06.012

Brown, C. (2021). Dummies: Create dummy/indicator variables flexibly and efficiently. CRAN-R. https://CRAN.R-project.org/package=dummies

Cerdà, A., Schnabel, S., Ceballos, A., Gomez-Amelia, D. (1998). Soil hydrological response under simulated rainfall in the Dehesa land system (Extremadura, SW Spain) under drought conditions. Earth Surf. Process. Landf. 23(3), 195-209. https://doi.org/10.1002/(SICI)1096-9837(199803)23:3<195::AID-ESP830>3.0.CO;2-I 
636

637

638

639

640

641

642

643

644

645

646

647

648

649

650

651

652

653

654

655

656

657

658

659

660

Chendeş, V. (2011). Resursele de apă din Subcarpaţii de la Curbură. Evaluări geospaţiale. Academy Publishing House, Bucharest, 339 pp.

Cheval, S., Breza T., Baciu M., Dumitrescu A. (2012). Caracteristici ale precipitatiilor atmosferice extreme din România pe baza curbelor intensitate-durata-frecventa. Sesiunea de comunicari stiintifice, Administratia Naţionala de Meteorologie, 8-9.

Costache, R., Arabameri, A., Blaschke, T., Pham, Q.B., Pham, B.T., Pandey, M., Arora, A., Linh, T.T.N., Costache, I. (2021a). Flash-Flood Potential Mapping Using Deep Learning, Alternating Decision Trees and Data Provided by Remote Sensing Sensors. Sensors 21(1), 280. https://doi.org/10.3390/s21010280

Costache, R., Barbulescu, A., Pham, Q.B. (2021b). Integrated Framework for Detecting the Areas Prone to Flooding Generated by Flash-Floods in Small River Catchments. Water 13(6), 758. https://doi.org/10.3390/w13060758

Costea, M. (2013). Land degradation through erosion in Romania in the eco-economic development context. International Multidisciplinary Scientific GeoConference: SGEM, 1,635 .

Dehn, M., Gärtner, H., \& Dikau, R. (2001). Principles of semantic modeling of landform structures. Computers \& Geosciences, 27(8), 1005-1010. https://doi.org/10.1016/S00983004(00)00138-2

Diaconu, C. (1971). Probleme ale scurgerii aluviunilor pe râurile din România, Studii de Hidrologie, XXX, IsMH Bucureşti.

Drobot, R., (2007). Methodology for determining torrential catchments in which human settlements are exposed to flash floods (in Romanian). Technical University of Civil Engineering, Bucharest, Romania.

EEA - European Environment Agency. (2018). Copernicus Land Monitoring Service - High Resolution land cover characteristics of Tree-cover/forest and change 2015-2018.

EEA - European Environment Agency. (2020). Copernicus Land Monitoring Service. Copernicus Land Monitoring Service High Resolution land cover characteristics. Copenhagen, Danemark: EEA. https://land.copernicus.eu/user-corner/technicallibrary/grassland-2018-user-manual.pdf. (accessed 14 June 2021).

Evans, R. (1997). Soil erosion in the UK initiated by grazing animals: a need for a national survey. Applied Geography, 17(2), 127-141. https://doi.org/10.1016/S01436228(97)00002-7

FAO (2021). Livestock Systems Key facts | Livestock Systems | Food and Agriculture Organization of the United Nations (fao.org) (accessed 10 June 2021).

FAOSTAT (2021). http://faostat.fao.org/[Online Database].

Friedman, J., Hastie, T., \& Tibshirani, R. (2000). Additive logistic regression: a statistical view of boosting (with discussion and a rejoinder by the authors). The annals of statistics, 28(2), 337-407. https://doi.org/10.1214/aos/1016218223

GAC. General Agricultural Census. (2010, 2011). General Agricultural Census. Romania. Herds of goats (heads), according to the legal status of agricultural holdings, by localities, http://www.rga2010.djsct.ro/inceput.php?cod=58\&codj=10.

Gayen, A., Haque, S.M., Saha, S. (2020) Modeling of Gully Erosion Based on Random Forest Using GIS and R. In: Shit P., Pourghasemi H., Bhunia G. (eds) Gully Erosion Studies from India and Surrounding Regions. Advances in Science, Technology \& Innovation (IEREK Interdisciplinary Series for Sustainable Development). Springer, Cham. https://doi.org/10.1007/978-3-030-23243-6_3

Gibbs, H. K., \& Salmon, J. M. (2015). Mapping the world's degraded lands. Applied geography, 57, 12-21.

Gifford, G.F., Hawkins, R.H. (1978). Hydrologic impact of grazing on infiltration: A critical review. Water Resour. Res. 14(2), 305-313. https://doi.org/10.1029/WR014i002p00305 
Gifford, G.F., Provenza, F.D., Malechek, J.C. (1983). Impact of range goats on infiltration rates in southwestern Utah. J. Range Manag. 36(2), 152-153.

Gomez-Zavaglia, A., Mejuto, J.C., Simal-Gandara, J. (2020). Mitigation of emerging implications of climate change on food production systems. Food Res. Int. 134, 109256. https://doi.org/10.1016/j.foodres.2020.109256

Goodarzi, M., Mohtar, R.H., Kiani-Harchegani, M., Faraji, A., Mankavi, F., Rodrigo-Comino, J. (2021). Evaluación del índice de pobreza hídrica (WPI) en la cuenca de BorujerdDorood (Irán) para reforzar los planes de gestión del territorio. Pirineos 176, e064. https://doi.org/10.3989/pirineos.2021.176002.

Hancock, G.R., Ovenden, M., Sharma, K., Rowlands, W., Gibson, A., Wells, T. (2020). Soil erosion - The impact of grazing and regrowth trees. Geoderma, 361(1), 114102. https://doi.org/10.1016/j.geoderma.2019.114102

Heathwaite, A. L., Burt, T.P., Trudgill, S.T. (1990). Land-use controls on sediment production in a lowland catchment, south-west England. In Soil erosion on agricultural land. Proceedings of a workshop sponsored by the British Geomorphological Research Group, Coventry, UK, January 1989. (pp. 69-86). John Wiley \& Sons Ltd.

Heathwaite, A.L., Burt, T.P., Trudgill, S.T. (1989). Runoff, sediment, and solute delivery in agricultural drainage basins: a scale-dependent approach. IAHS. 182, 175-191. http://www.rga2010.djsct.ro/inceput.php?cod $=58 \& \operatorname{codj}=10$

Ho, T. K. (1995). Random decision forests. In Proceedings of 3rd international conference on document analysis and recognition (Vol. 1, pp. 278-282). IEEE. https://doi.org/10.1109/ICDAR.1995.598994

Ielenicz, M. (1984), Munţii Ciucaş - Buzău, Studiu geomorfologic. Editura Academiei Române, Bucureşti.

IGR. (1968). Romanina Institue of Geology, 1968. Romanian Geological Map 1:2000000, Bucharest, retrieved from: http://www.geo-spatial.org/download/harta-geologica-aromaniei-scara-1-200-000

Ioana-Toroimac, G. (2016). Inventory of long-term braiding activity at a regional scale as a tool for detecting alterations to a rivers' hydromorphological state: a case study for Romania's South-Eastern Subcarpathians, Environ. Manage. 58, 93-106. https://doi.org/10.1007/s00267-016-0701-7

Ionita, I. (2006). Gully development in the Moldavian Plateau of Romania. Catena, 68(2-3), 133-140. http://dx.doi.org/10.1016/j.catena.2006.04.008

Ionita, I., Radoane, M., \& Mircea, S. (2006). Soil erosion in Europe. Soil erosion in Romania, John Boardman J., Poesen J. (Eds), John Willey, England, 155-167.

IPCC. (2019). Summary for Policymakers. In: Climate Change and Land: an IPCC special report on climate change, desertification, land degradation, sustainable land management, food security, and greenhouse gas fluxes in terrestrial ecosystems [P.R. Shukla, J. Skea, E. Calvo Buendia, V. Masson-Delmotte, H.- O. Pörtner, D. C. Roberts, P. Zhai, R. Slade, S. Connors, R. van Diemen, M. Ferrat, E. Haughey, S. Luz, S. Neogi, M. Pathak, J. Petzold, J. Portugal Pereira, P. Vyas, E. Huntley, K. Kissick, M. Belkacemi, J. Malley, (eds.)]. In press. https://www.ipcc.ch/srccl/ (accessed 10 June 2021).

Jurchescu M., Kucsicsa G., Micu M., Sima M., Bălteanu D. (2020). Landslide exposure assessment under environmental change in the Romanian Subcarpathians. Studia Geomorphologica Carpatho-Balcanica, LIII-LIV, 59-84.

Kidron, G.J. (2016). Goat trampling affects plant establishment, runoff and sediment yields over crusted dunes. Hydrol. Process. 30(13), 2237-2246. https://doi.org/10.1002/hyp.10794 
Kidron, G. J., Veste, M., \& Lichner, L. (2021). Biological factors impacting hydrological processes: Pecularities of plants and biological soil crusts. Journal of Hydrology and Hydromechanics, 69(4) 357-359. https://doi.org/10.2478/johh-2021-0031

Kosmas, C., Detsis, V., Karamesouti, M., Kounalaki, K., Vassiliou, P., Salvati, L. (2015). Exploring Long-Term Impact of Grazing Management on Land Degradation in the Socio-Ecological System of Asteroussia Mountains, Greece. Land, 4, 541-559. https://doi.org/10.3390/land4030541

Kuhn, M. (2008). Building Predictive Models in R Using the caret Package. Journal of Statistical Software 28 (5): 1 -26.

Kulik, M., Warda, M., \& Leśniewska, P. (2013). Monitoring the diversity of psammophilous grassland communities in the Kózki Nature Reserve under grazing and non-grazing conditions. Journal of Water and Land Development, 19, 59-67.

Lai, L., Kumar, S. (2020). A global meta-analysis of livestock grazing impacts on soil properties. PloS one 15(8), e0236638. https://doi.org/10.1371/journal.pone.0236638

Langanke, T. (2018). Copernicus Land Monitoring Service - High Resolution Layer Grassland. Copenhagen, Denmark: EEA. https://land.copernicus.eu/usercorner/technical-library/hrl-grassland-technical-document-prod-2015. (accessed 15 June 2021).

Lázaro, R., Calvo-Cases, A., Arnau-Rosalén, E., Rubio, C., Fuentes, D. \& López-Canfín,C. (2021). Defining minimum runoff length allows for discriminating biocrusts and rainfall events. Journal of Hydrology and Hydromechanics, 69(4) 387-399. https://doi.org/10.2478/johh-2021-0029

Ma, L., Derner, J. D., Harmel, R. D., Tatarko, J., Moore, A. D., Rotz, C. A., ... \& Wilmer, H. (2019). Application of grazing land models in ecosystem management: Current status and next frontiers. Advances in Agronomy, 158, 173-215.

Markart, G., Kohl, B., Kirnbauer, R., Pirkl, H., Bertle, H., Stern, R., Reiterer, A., Zanetti, P. (2006). Surface runoff in a torrent catchment area in Middle Europe and its prevention. Geotech. Geol. Eng. 24(5), 1403-1424. https://doi.org/10.1007/s10706-005-2633-5

Meyles, E., Williams, A., Ternan, L., Dowd, J. (2003). Runoff generation in relation to soil moisture patterns in a small Dartmoor catchment, Southwest England. Hydrol. Process. 17(2), 251-264. https://doi.org/10.1002/hyp.1122

Meyles, E.W., Williams, A.G., Ternan, J.L., Anderson, J.M., Dowd, J.F. (2006). The influence of grazing on vegetation, soil properties and stream discharge in a small Dartmoor catchment, southwest England, UK. Earth Surf. Process. Landf. 31(5), 622-631. https://doi.org/10.1002/esp.1352

Micu, M. (2017). Landslide Types and Spatial Pattern in the Subcarpathian Area. In: Radoane M., Vespremeanu-Stroe A. (eds) Landform Dynamics and Evolution in Romania. Springer Geography. Springer, Cham. https://doi.org/10.1007/978-3-319-32589-7_1

Micu, M., \& Balteanu, D. (2009). Landslide hazard assessment in the Curvature Carpathians and Subcarpathians, Romania. Zeitschrift für Geomorphologie, Supplementary Issues, 31-47. DOI: 10.1127/0372-8854/2009/0053S3-0031

Mishra, S. K., \& Singh, V. (2003). Soil conservation service curve number (SCS-CN) methodology (Vol. 42). Springer Science \& Business Media.

Mockus, V. (2012). Hydrologic Soil Groups. In National Engineering Handbook - Part 630 Hydrology, edited by USDA, 1-13. Washington: USDA.

Morales, F.D.A.R., Genís, J.M.C., Guerrero, Y.M. (2019). Current status, challenges and the way forward for dairy goat production in Europe. Asian-Australas J. Anim. Sci. 32(8), 1256-1265. https://doi.org/10.5713/ajas.19.0327

Mor-Mussery, A., Abu-Glion, H., Shuker, S., Zaady, E. (2021). Small Ruminants Grazing as a Rehabilitative Land Management Tool in the Negev Highland; Soil, Geomorphological 
and Topographical Perspectives.

Agronomy,

11,

1730. https://doi.org/10.3390/agronomy11091730

Mosavi, A., Golshan, M., Janizadeh, S., Choubin, B., Melesse, A. M., \& Dineva, A. A. (2020). Ensemble models of GLM, FDA, MARS, and RF for flood and erosion susceptibility mapping: a priority assessment of sub-basins. Geocarto International, 1-20. https://doi.org/10.1080/10106049.2020.1829101

Mwendera, E.J., Saleem, M.M. (1997). Hydrologic response to cattle grazing in the Ethiopian highlands. Agric. Ecosyst. Environ. 64(1), 33-41. https://doi.org/10.1016/S01678809(96)01127-9

Nadal-Romero, E., Lasanta, T., Cerdà, A. (2018). Integrating Extensive Livestock and Soil Conservation Policies in Mediterranean Mountain Areas for Recovery of Abandoned Lands in the Central Spanish Pyrenees. A Long-Term Research Assessment. Land Degrad. Develop. 29(2), 262-273. https://doi.org/10.1002/ldr.2542

National Institute of Statistics of Romania - INSSE. (2021). Land fund area by usage, counties and localities. https://insse.ro/cms/en

Neculau, G., Minea, G., Ciobotaru N., Ioana-Toroimac G., Mircea S., Mititelu-Ionuș, O., Rodrigo-Comino, J. (2021). A Survey of Farmer Perception about Grazing: A Case Study of the Curvature Subcarpathians, Romania. Journal of Water and Land Development, in press.

Niacsu, L., Ionita, I., Samoila, C., Grigoras, G., \& Blebea-Apostu, A. M. (2021). Land Degradation and Soil Conservation Measures in the Moldavian Plateau, Eastern Romania: A Case Study from the Racova Catchment. Water, 13(20), 2877. https://doi.org/10.3390/w13202877

Nicu, I. C. (2018). Is overgrazing really influencing soil erosion?. Water, 10(8), 1077, http://dx.doi.org/10.3390/w10081077.

Niu, Y.H., Wang, L., Wan, X.G., Peng, Q.Z., Huang, Q., Shi, Z.H. (2021). A systematic review of soil erosion in citrus orchards worldwide. Catena 206, 105558. https://doi.org/10.1016/j.catena.2021.105558

Oertel, C., Matschullat, J., Zurba, K., Zimmermann, F., Erasmi, S. (2016). Greenhouse gas emissions from soils - A review. Geochemistry, 76(3), 327-352.

Olariu, P., Cojoc, G.M., Tirnovan, A., Obreja, F. (2014). The future of reservoirs in the Siret River Basin considering the sediment transport of rivers (Romania). Georeview, 1-11. https://doi.org/10.4316/GEOREVIEW.2014.24.1.169

Panagos, P., Ballabio, C., Borrelli, P., Meusburger, K., Klik, A., Rousseva, S., ... \& Alewell, C. (2015). Rainfall erosivity in Europe. Science of the Total Environment, 511, 801-814. https://doi.org/10.1016/j.scitotenv.2015.01.008

Pande, T.N., Yamamoto, H. (2006). Cattle treading effects on plant growth and soil stability in the mountain grassland of Japan. Land Degrad. Dev. 17(4), 419-428. https://doi.org/10.1002/ldr.747

Papanastasis, V.P., Peter, D. (1998). Ecological basis of livestock grazing in mediterranean ecosystems. Proceedings of the International Workshop held in Thessaloniki, October 23-25, 1997. Brussels: European Comission, 350 pp.

Part 630 Hydrology, edited by USDA, 1-13. Washington: USDA.

Peppler, M.C., Fitzpatrick, F.A. (2004). Methods for Monitoring the Effects of Grazing Management on Bank Erosion and Channel Morphology, Fever River, Pioneer Farm, Wisconsin. https://pubs.usgs.gov/fs/2005/3134/pdf/FS_2005-3134.pdf (accessed 24 October 2021) 
Posea, G., Badea, L. (1984). România - unităţile de relief (Regionarea geomorfologică), Hartă, scara 1:750.000 Editura Ştiinţifică şi Enciclopedică, Bucureşti.

Poesen, J. (2018). Soil erosion in the Anthropocene: Research needs. Earth Surf. Process. Landf. 43(1), 64-84. https://doi.org/10.1002/esp.4250

Prăvălie, R., Săvulescu, I., Patriche, C., Dumitraşcu, M., \& Bandoc, G. (2017). Spatial assessment of land degradation sensitive areas in southwestern Romania using modified MEDALUS method. Catena, 153, 114-130.

Pulido, M., Barrena-González, J., Badgery, W., Rodrigo-Comino, J., Cerdà, A. (2018). Sustainable grazing. Current Opinion in Environmental Science \& Health, Sustainable soil management and land restoration 5, 42-46. https://doi.org/10.1016/j.coesh.2018.04.004

Pulley, S., Collins, A.L. (2019). Field-based determination of controls on runoff and fine sediment generation from lowland grazing livestock fields. J. Environ. Manage. 249, 109365. https://doi.org/10.1016/j.jenvman.2019.109365

Ries, J. B., Andres, K., Wirtz, S., Tumbrink, J., Wilms, T., Peter, K. D., ... \& Seeger, M. (2014). Sheep and goat erosion-experimental geomorphology as an approach for the quantification of underestimated processes. Zeitschrift für Geomorphologie, 58(3), 023045, http://dx.doi.org/10.1127/0372-8854/2014/S-00158.

Ritchie, H., Roser, M. (2017). Meat and dairy production. Published online at OurWorldInData.org. Retrieved from: https://ourworldindata.org/meatproduction\#citation, $\% 20$ accessed $\% 2010.06 .2021$

Riva, M. J., Daliakopoulos, I. N., Eckert, S., Hodel, E., \& Liniger, H. (2017). Assessment of land degradation in Mediterranean forests and grazing lands using a landscape unit approach and the normalized difference vegetation index. Applied geography, 86, 8-21.

Rodrigo-Comino, J. (2018). Five decades of soil erosion research in "terroir". The State-ofthe-Art. Earth-Science Reviews 179, 436-447. https://doi.org/10.1016/j.earscirev.2018.02.014

Rodriguez-Lloveras, X., Bussi, G., Francés, F., Rodriguez-Caballero, E., Solé-Benet, A., Calle, M., \& Benito, G. (2015). Patterns of runoff and sediment production in response to landuse changes in an ungauged Mediterranean catchment. Journal of Hydrology, 531, 10541066.https://doi.org/10.1016/j.jhydrol.2015.11.014

Roman, A., Ursu, T. M., Onțel, I., Marușca, T., Pop, O. G., Milanovici, S., ... \& Frink, J. P. (2019). Deviation from grazing optimum in the grassland habitats of Romania within and outside the natura 2000 network. In Habitats of the World-Biodiversity and Threats. IntechOpen.

Ruggenthaler, R., Schöberl, F., Markart, G., Klebinder, K., Hammerle, A., Leitinger, G. (2015). Quantification of soil moisture effects on runoff formation at the hillslope scale. J. Irrig. Drain. Eng. 141(9), 05015001. https://doi.org/10.1061/(ASCE)IR.1943-4774.0000880

Sadeghi, S.H.R., Vangah, B.G., Safaeeian, N.A. (2007). Comparison between effects of open grazing and manual harvesting of cultivated summer rangelands of northern Iran on infiltration, runoff and sediment yield. Land Degrad. Dev. 18(6), 608-620. https://doi.org/10.1002/ldr.799

Sahin, Emrehan Kutlug. (2020). Assessing the predictive capability of ensemble tree methods for landslide susceptibility mapping using XGBoost, gradient boosting machine, and random forest. SN Applied Sciences 2, no. 7 1-17.

Shirasaka, S. (2007). The transhumance of sheep in the southern Carpathians Mts., Romania. Geographical Review of Japan, 80(5), 290-311. https://doi.org/10.4157/grj.80.290 
Staddon, P. L., \& Faghihinia, M. (2021). Grazing intensity is key to global grassland carbon $\begin{array}{llll}\text { sequestration } & \text { potential. Sustainable } & \text { Environment, 7(1), } & 1895474 .\end{array}$ https://doi.org/10.1080/27658511.2021.1895474

Steinfeld, H., Gerber, P., Wassenaar, T.D., Castel, V., Rosales, M., Rosales, M., de Haan, C. (2006). Livestock's long shadow: environmental issues and options. Food \& Agriculture Org., Rome, Italy.

Turnbull, L., Wainwright, J., Brazier, R.E. (2010). Changes in hydrology and erosion over a transition from grassland to shrubland. Hydrol. Process. 24(4), 393-414. https://doi.org/10.1002/hyp.7491

Vintilă, R., Munteanu, I., Cojocaru, G., Radnea, C., Turnea, D., Curelariu, G., ... \& Vespremeanu, R. (2004). Sistemul Informatic Geografic al Resurselor de Sol ale României "SIGSTAR-200": Metodologie de realizare şi principalele tipuri de aplicaţii. Lucrările celei de a XVII-a Conferinţe Naţionale pentru Ştiinţa Solului, 1, 439.

Vojtek, M., Vojteková, J., Costache, R., Pham, Q. B., Lee, S., Arshad, A., Sahoo S., Linh, N.T.T., Anh, D.T. (2021). Comparison of multi-criteria-analytical hierarchy process and machine learning-boosted tree models for regional flood susceptibility mapping: a case study from Slovakia. Geomatics, Nat. Hazards Risk 12(1), 1153-1180. https://doi.org/10.1080/19475705.2021.1912835.

Vörösmarty, C.J., Sahagian, D. (2000). Anthropogenic disturbance of the terrestrial water cycle. Bioscience 50(9), 753-765. https://doi.org/10.1641/00063568(2000)050[0753:ADOTTW]2.0.CO;2

Warren, S.D., Thurow, T.L., Blackburn, W.H., Garza, N.E. (1986). The influence of livestock trampling under intensive rotation grazing on soil hydrologic characteristics. J. Range Manag. 39(6), 491-495. https://doi.org/10.2307/3898755

Weiss, A., D. (2001). Topographic position and landforms analysis - Poster. San Diego: ESRI Users Conference.

WHO (2020), Climate change: Land degradation and desertification, https://www.who.int/news-room/q-a-detail/climate-change-land-degradation-anddesertification, (accessed 21 June 2021).

Wolański, P., Bobiec, A., Ortyl, B., Makuch-Pietraś, I., Czarnota, P., Ziobro, J., Korol, M., Havryliuk, S.,Paderewski, J., Kirby, K. (2021).The importance of livestock grazing at woodland-grassland interface in the conservation of rich oakwood plant communities in $\begin{array}{llll}\text { temperate } & \text { Europe. } & \text { Biodivers. Conserv. }\end{array}$ https://link.springer.com/article/10.1007\%2Fs10531-021-02115-9

Zaharia L., Ioana-Toroimac G. (2009). Erosion dynamics - precipitation relationship in the Carpathians Curvature region (Romania). Geogr. Fis. Din. Quat. 32(1), 95-102.

Zaharia, L., Grecu F., Ioana-Toroimac, G., Neculau G. (2011). Sediment transport and river channel dynamics in Romania - variability and control factors. In: Manning A.J., Sediment Transport in Aquatic Environments, Intechopen, Rijeka, 293-316. https://doi.org/10.5772/21416

Zamfir, A., \& Crişu, L. (2021). Estimating Soil Erosion Exerted by Water in the Lower Sector of the Jiu River Floodplain and Băilești Plain. Forum geografic, XX(1), 24-33. https://doi:10.5775/fg.2021.112.i

Zavoianu, I., Muica, C., Alexandrescu, M. (1996). The critical environment of the Subcarpathian region of Romania (state-of-the-art). Geograficky Casopis Slovenskej Akademie Vied, 48, 105-112.

Zeug, G., Tumampos, S., Buchauer, M., Pennec, A., Dufourmont. H. (2020). GMES Initial Operations/Copernicus Land monitoring services - Validation of products. Copenhagen, Denmark: $\quad$ EEA. $\quad$ https://land.copernicus.eu/user-corner/technicallibrary/clms hrl_gra_validation_report_sc04_v1_5.pdf (accessed 15 June 2021). 
903 http://geospatial.org/ 904 


\section{Figures}

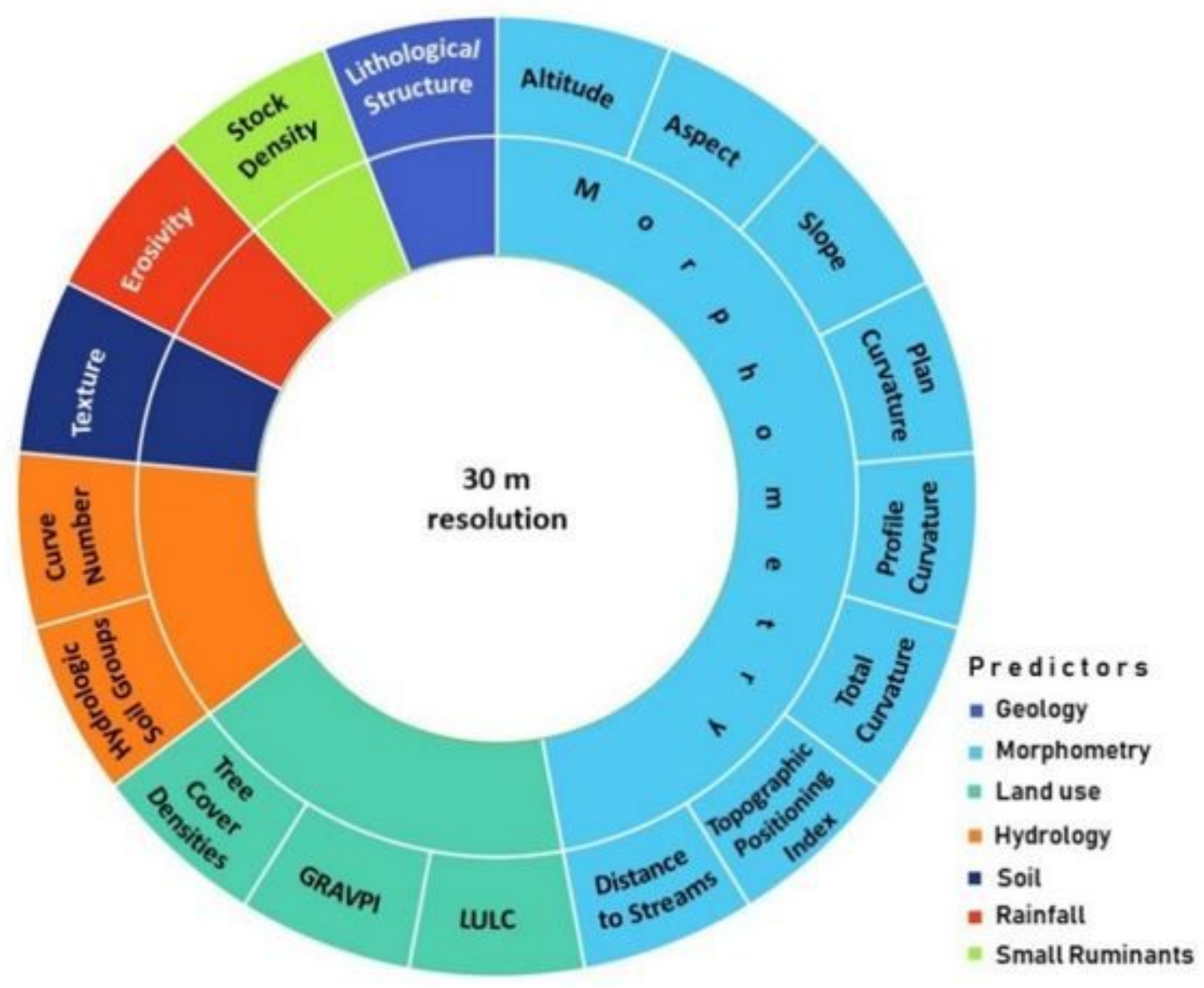

\section{Figure 1}

The proposed hierarchy predictors and their geographical use to develop the Grazing Susceptibility to Land Degradation Index. (GRAVIPA = Grassland Vegetation Probability Index; LULC = Land Use Land Cover) 


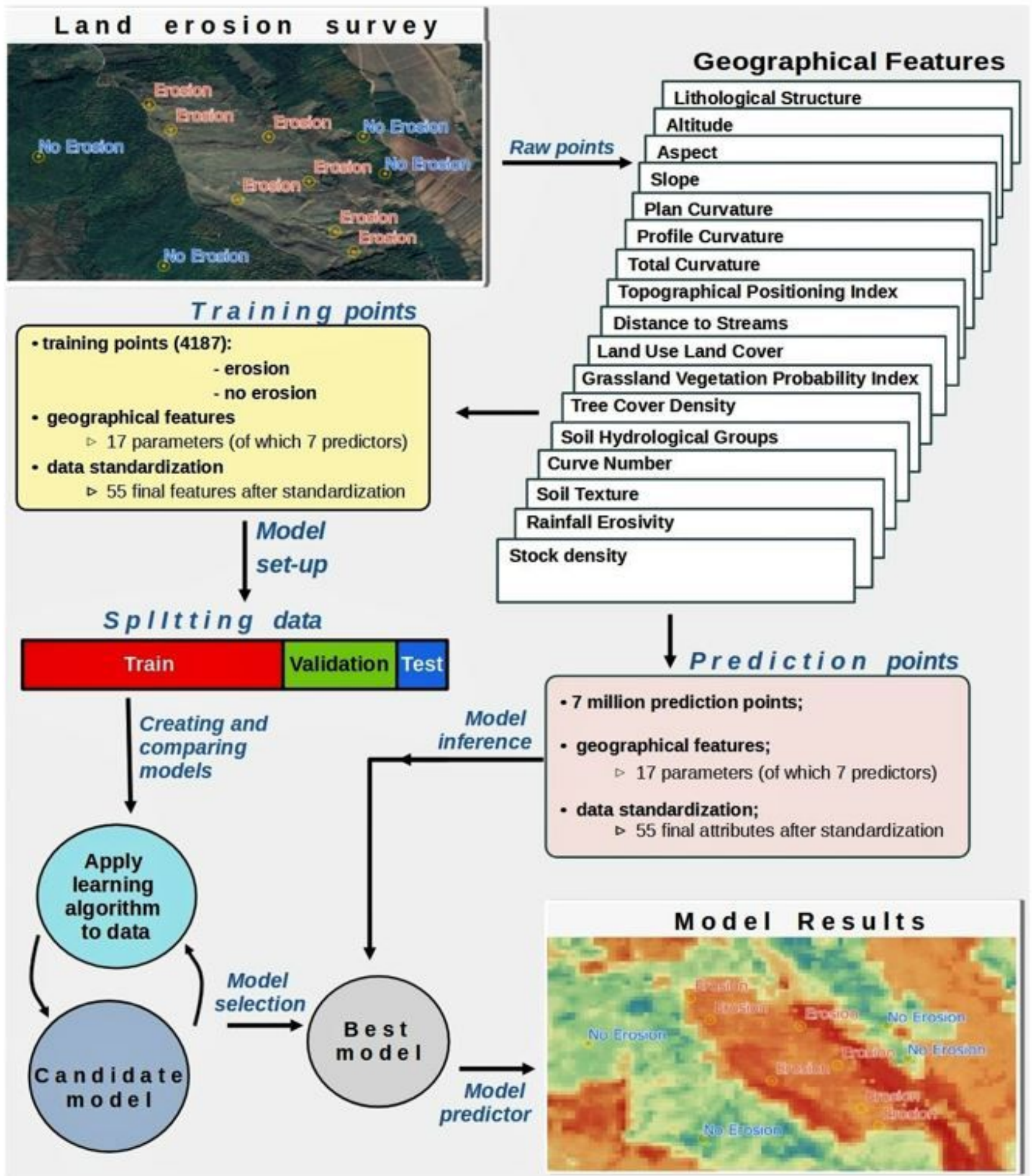

Figure 2

Workflow for designing Grazing Susceptibility to Land Degradation Index 


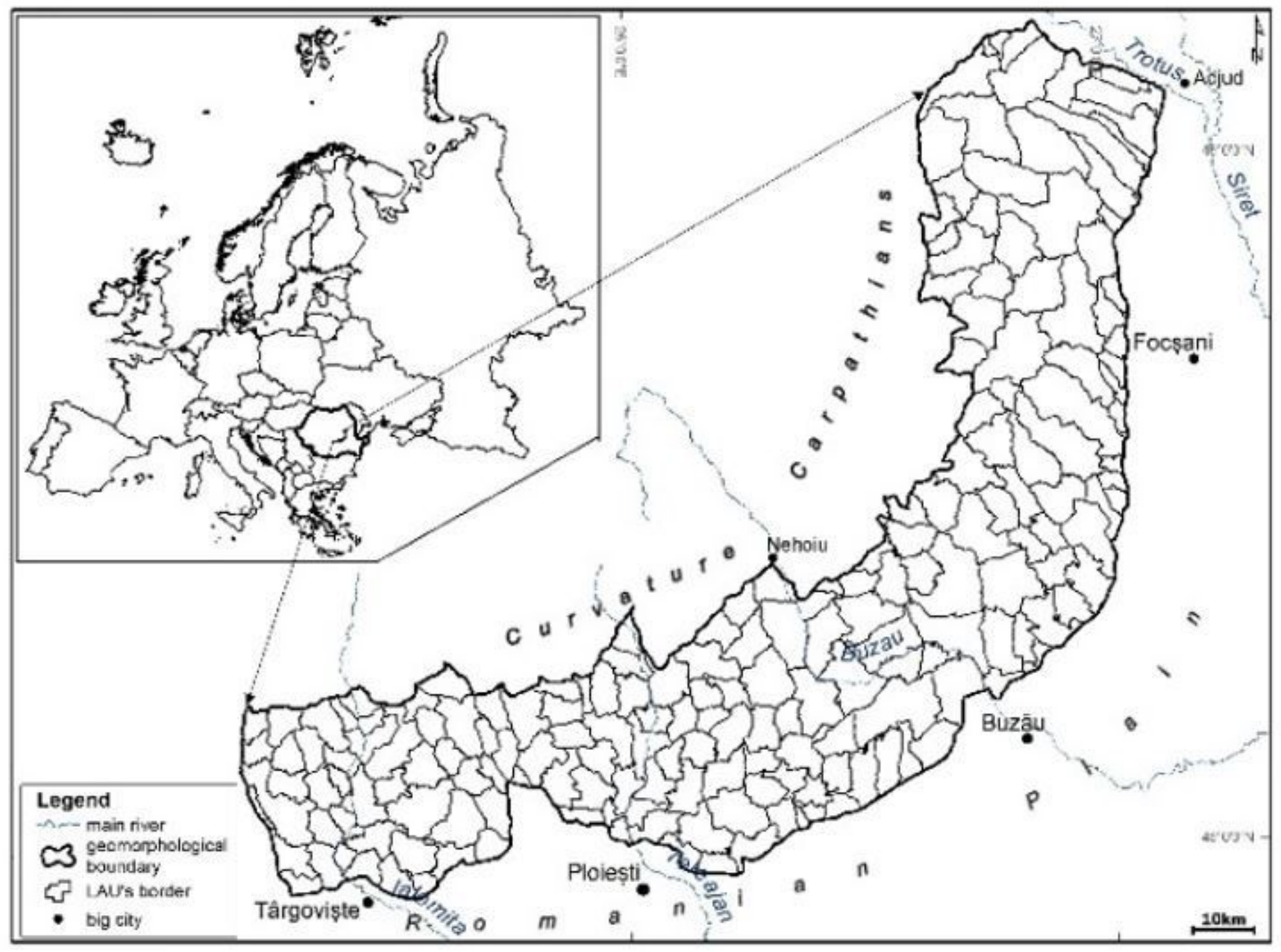

Figure 3

The location of Curvature Subcarpathians and the border of Local Administrative Units level 2 


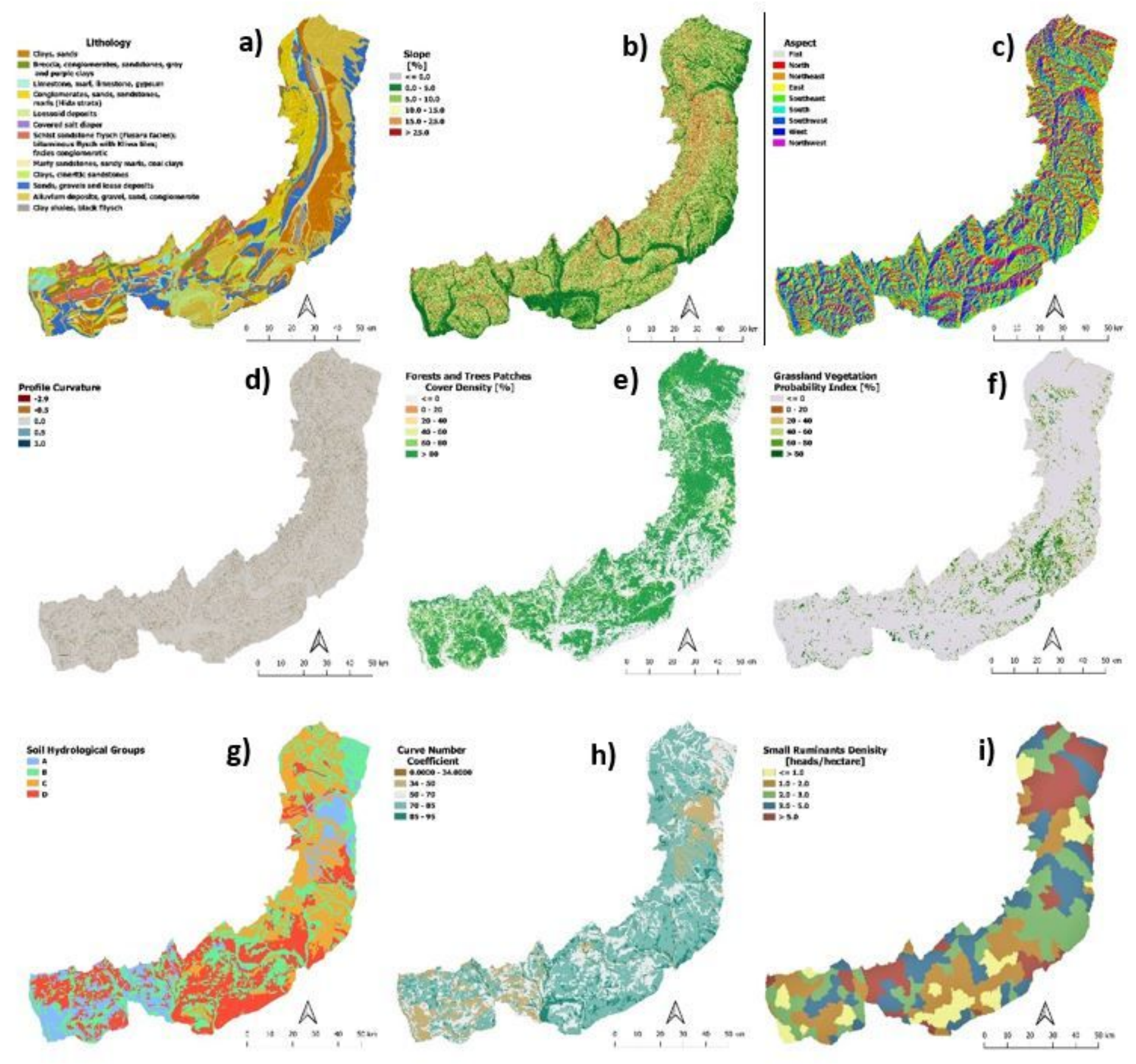

Figure 4

Curvature Subcarpathians geographic factors: a) Lithology; b) Slope angle; c) Aspect; d) Profile Curvature; e) Forest and Trees Patches Cover Density; f) GRAVPI; g) Hydrologic Soil Groups; h) Curve number; i) SRs Density. 


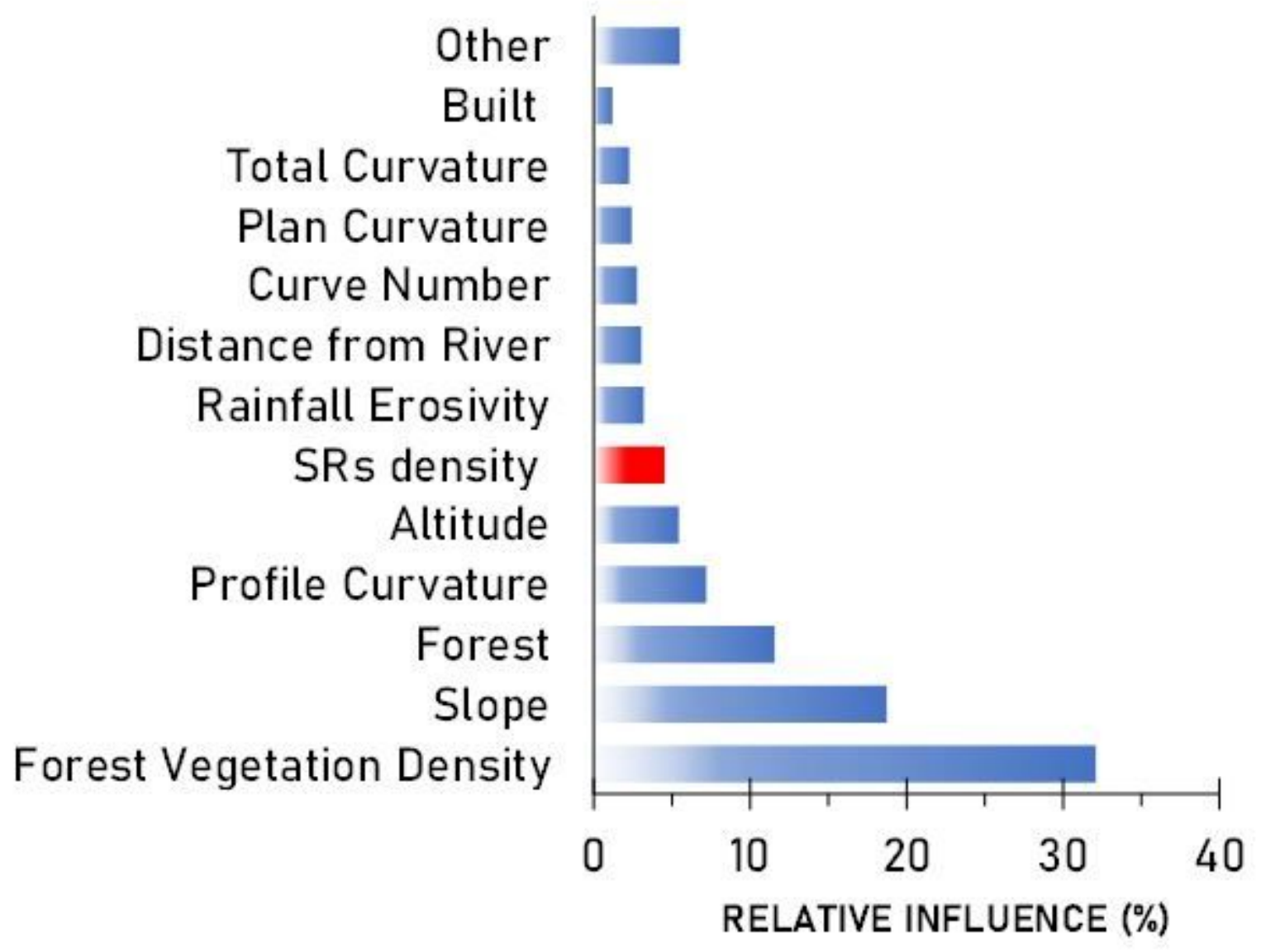

Figure 5

Conditional factors and their relative influence (\%) / share/rank (\%) to land degradation in the Curvature Subcarpathians region under GBM 


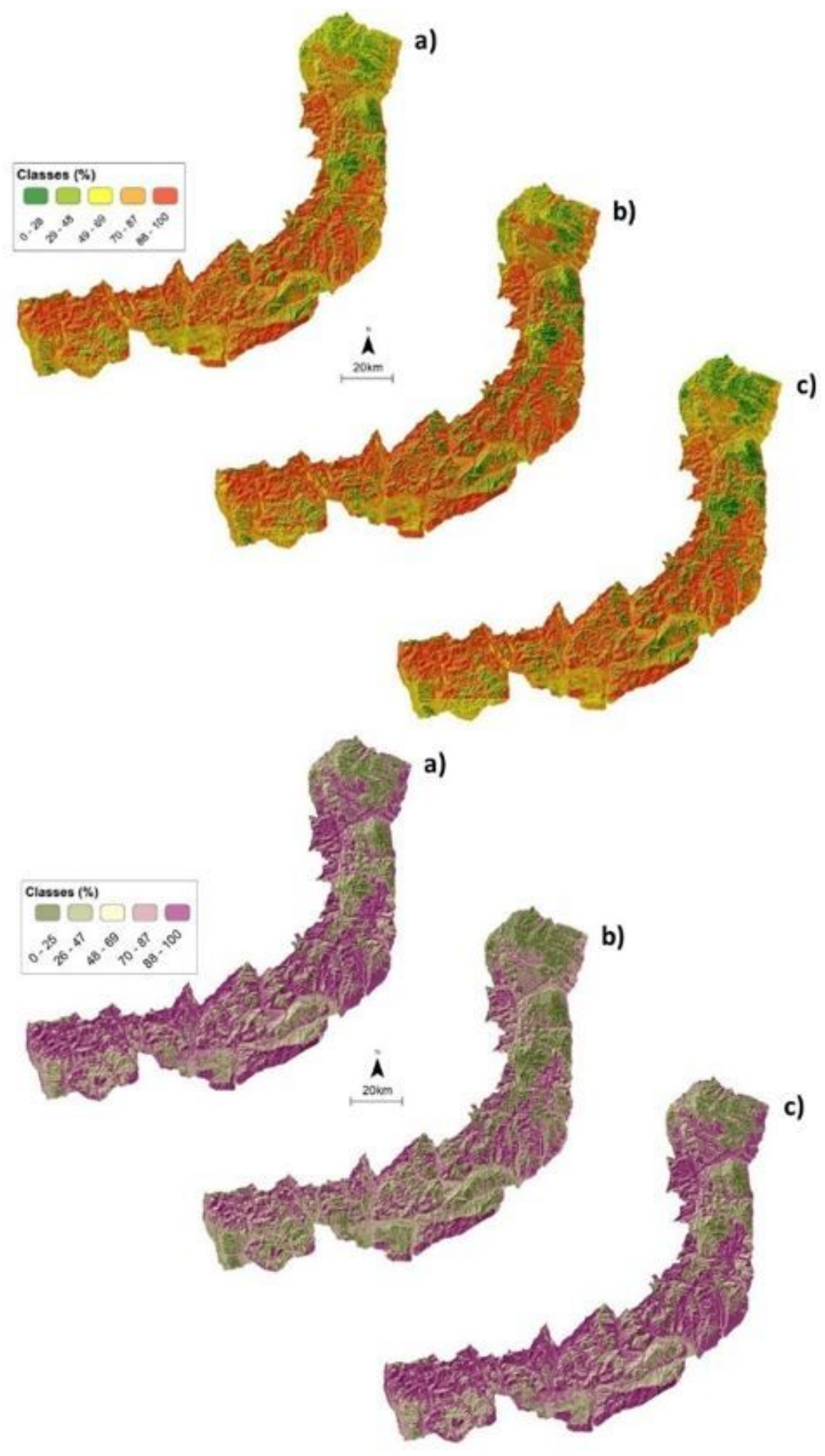

Figure 6

GSLDI probabilistic maps (0 -100\%) in CS region with Random Forest (first/up 3 images) and Gradient Boosted Machine (second/down 3 images) under initial a), zero b), and 100\% overstocking c) scenarios 


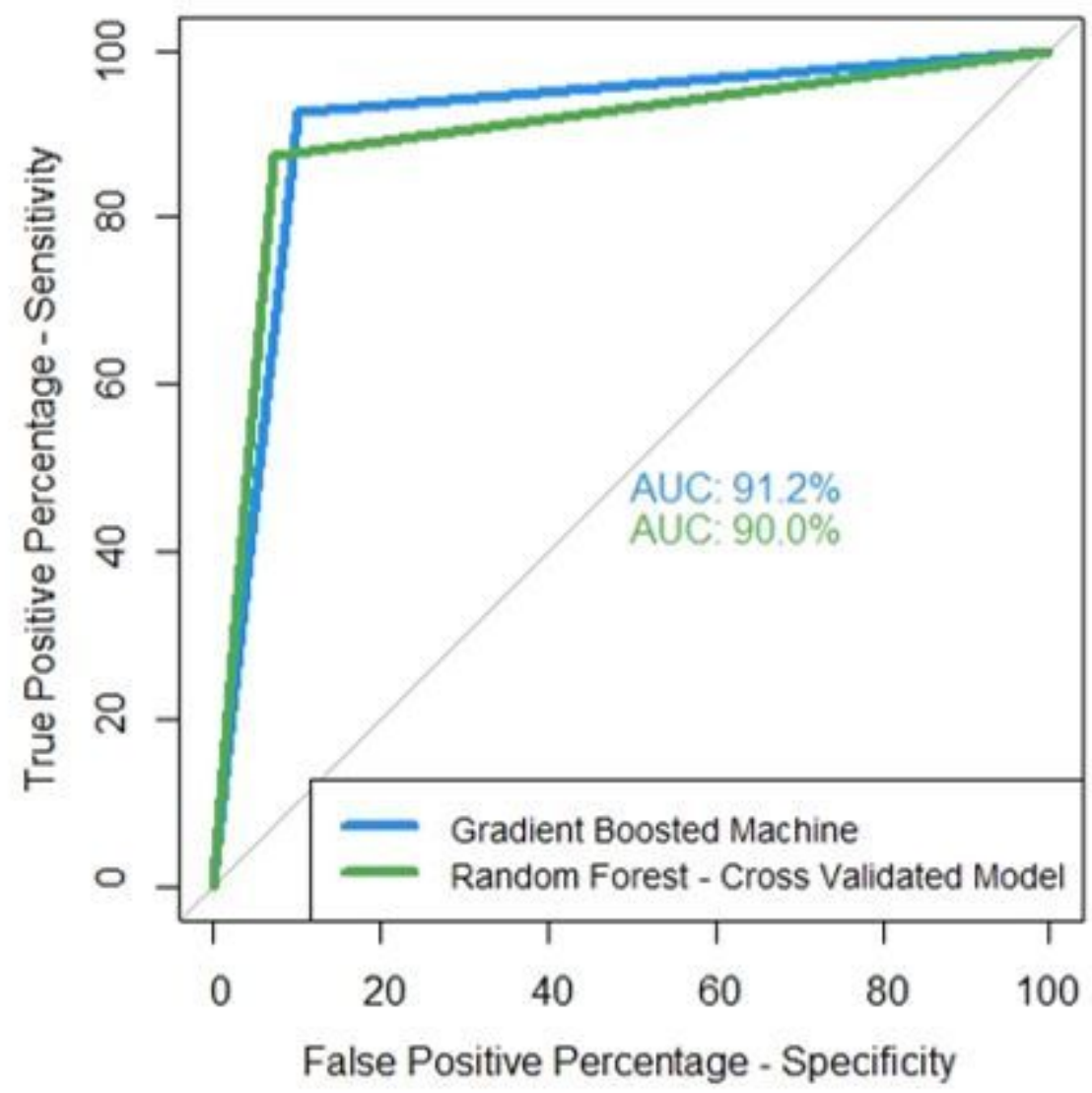

Figure 7

ROC curves with associated AUC values computed

from Gradient Boosted Machine and Random Forest

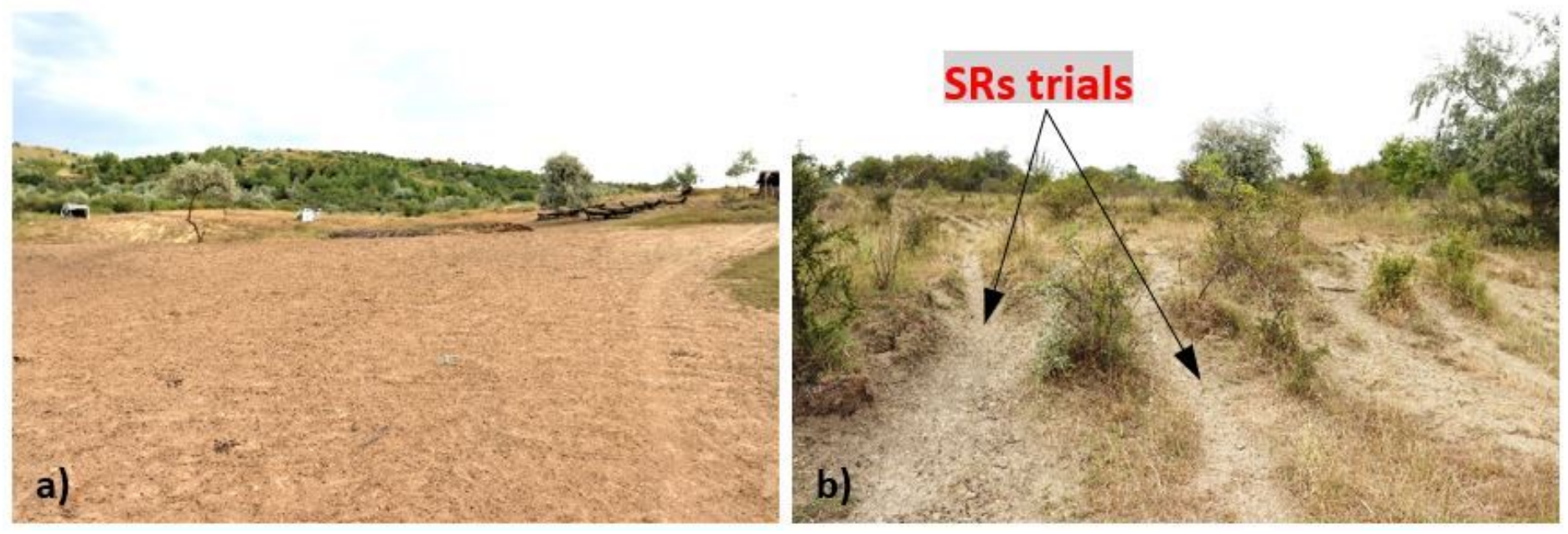

Figure 8 
Field photographs showing the sheet and linear (rill) grazing impact of SRs photos - near paddock (a) and trails (b) in the Curvature Subcarpathians, Romania; photograph taken by Gabriel MINEA on August $18^{\text {th }}, 2021$

\section{Supplementary Files}

This is a list of supplementary files associated with this preprint. Click to download.

- SupplementaryMaterialS1.xlsx 